\title{
Exploring Place Branding: State of the Art and Future Research Directions
}

\author{
Berrada Mohamed \\ Université Privée de Marrakech, Marrakesh, Morocco
}

\begin{abstract}
During these last years, place branding has gained in popularity among local officials, institutional stakeholders, academic authors, and researchers since it has become a relevant topic at the heart of places' issues of development, promotion, and attractiveness. Several disciplines have contributed separately to the development of place branding highlighting various concepts and different variables; however, the emergence recently of a convergence has led to a more comprehensive view of the subject and to expand its research platform by unveiling new issues. The interest of this paper is to put the place branding in its context, go back to its origins in order to understand its evolution, define it, and explain its conceptual development to come out at the end with future research tracks.
\end{abstract}

Keywords: place branding, marketing, development, attractiveness, promotion

\section{Introduction}

Nowadays, we live in a globalized and interconnected world that turns into one market. Countries, regions and cities have then to distinguish and differentiate each other, creating a competition between places that call out strategy to build a competitive advantage. This differentiation strategy aims to increase the attractiveness and competitiveness of places to win their global share of customers, tourists, investors, businesses, capital, students, events, as well as the respect and attention of other countries and international media. This competitive environment is not a reality of modern times as the fight engaged by places to seek a competitive advantage dates back to the 19th century when place promotion emerged as a solution to this increased place competition. Indeed, places, throughout history, have always promoted their attractions and their images because they needed to attract residents, customers, visitors, traders, investors, and the class of people we call today “influencers" (Anholt, 2010, p. 1). Places' competition has become even fiercer especially with the rapid development of tourism and the growing need to attract foreign investment to revitalize places (Ward, 1998). Therefore, place promotion has become, from the 1970s, a key strategy in urban policies and the tourism industry (Kavatzis \& Ashworth, 2005). Over time, places have acquired an image and forged a reputation and the major concern of today's governments is to improve them with the international community, because the way in which places will define and communicate their unique position in the world market, will allow knowing which ones will succeed in the race for attractiveness and economic prosperity, and others that will

Berrada Mohamed, Ph.D., prof., Department of Business and Governance, Université Privée de Marrakech, Marrakesh, Morocco.

Correspondence concerning this article should be addressed to Berrada Mohamed, Université Privée de Marrakech km 13, route d’Amizmiz, Marrakech 42312, Morocco. 
fail. In such a competitive environment, how can places develop and increase their attractiveness internationally? How can they promote their place offer and differentiate it from others?

These issues of attractiveness, differentiation, and customization of the offer have contributed to the birth of place marketing which aims to create the uniqueness sought by places and enhance their attractiveness factors to ultimately improve their competitive position. Moreover, place marketing formation has been facilitated by the theoretical developments in marketing that helped understand the various implications of this discipline in management and urban planning (Ashworth \& Voogd, 1990). Thereby, authors and researchers in the marketing literature consider the passage of place marketing to place branding as a logical and inevitable evolution (Gertner \& Kotler, 2004). On the one hand, extensive use and success of product branding and corporate branding have facilitated this transition (Balmer \& Greyser, 2003), and on the other hand, places or more specially cities have always been perceived as brands, and are even more so today in the time of globalization. For a long time, governments have been trying to give meaning to their territories to form a specific place identity and to promote it to target markets, therefore, branding offers to local officials that possibility by allowing them to pursue and achieve different economic, political, and socio-psychological goals (Hankinson, 2001; Kavaratzis \& Ashworth, 2005; Rainisto, 2003).

The purpose of this paper is to explore the new phenomenon of place branding to better understand this discipline under construction, as well as identify potential areas of research to capitalize on to develop and complete existing place branding literature and theory.

\section{Place Branding Field}

\section{The Discipline Origins: Historical Perspective}

It is difficult to put a precise date on the appearance of the place branding concept but what is certain is that the practice of place promotion is not recent at all. Indeed, the link between brands and places dates back to the time of Alexander the Great (356-323 BC), which considered that places' success or failure depended closely on the projected image beyond their borders (Anholt, 2008). For their part, Kavaratzis and Ashworth (2005) argued that the attempt by governments to form and promote a place identity to external or internal target markets is almost as old as the governments themselves. Nevertheless, the practice of promoting a geographical area for visitors, residents, and investors has grown rapidly over the past two decades accompanied by a progressive sophistication of techniques and purposes (Pasquinelli, 2012).

From a historical perspective, place branding activities have emerged from the United States during the 19th century (Hankinson, 2010; Govers \& Go, 2009) and have focused on creating the differentiation and preference effect based mainly on advertising and promotion (Ward, 1998). New York was the first city to create the brand "I love NY" in 1977 by Milton Glaser. The brand designed initially to promote tourism in the State of New York, managed to prove its effectiveness and thus became a world-famous brand. It is important to note that the literature produced was focused much more on the "place promotion" or "place selling" rather than on place branding itself (Kearns \& Philo, 1993; Gold \& Ward, 1994). This literature published in the years 1970-1980 has drawn its foundation of two distinct areas that are urban policy by developing the urban image and tourism by promoting the destination image. The late 80s and the early 90s witnessed the first attempts to create a literary approach to place marketing. Indeed, this period saw the publication of some work that formed the basis of this discipline, including City Marketing: Instruments and Effects (Bartels \& Timmer, 1987), Selling the City 
(Ashworth \& Voogd (1990), Marketing Metropolitan Regions (van den Berg, Klaasen, \& van der Meer, 1990) and Marketing Places: Attracting Investment, Industry, and Tourism to Cities, States, and Nations (Kotler, Haider, \& Rein, 1993) which is one of the fundamental references in the literature. Accordingly, the strategic importance of marketing grew and it has become an essential component for the study and management of places. Its systematic application was relevant to achieve places' collective goals. Since then, marketers have continued to refine their concepts and ideas; place marketing became then a common activity of cities, regions, and countries.

The transition from place marketing to place branding occurred in the late 90s and early 2000s. Places have followed the example of organizations by importing the various concepts and techniques of product branding and especially corporate branding in their own operational area in order to improve their position in a globalized and competitive environment.

This interest toward branding appears to be the current episode in the development of place marketing (Kavaratzis, 2009). In the literature, Simon Anholt (1998) was the first to invent and use the term "nation branding" in his article "Nation Brands of the Twenty-First Century", emphasizing the difference between place marketing and place branding. Articles on this theme have since increased and were published in various specialized journals in urban planning, tourism, geography, and more recently in marketing. Following this, several academic journals related to places' management, marketing, and branding (i.e., cities, regions, countries, and destinations) have emerged including: Place Branding and Public Diplomacy, Journal of Destination Marketing and Management, Journal of Place Management and Development, Journal of Brand Management, and Journal of Marketing Management.

Three stages have been previously identified where one does not replace the other, but rather can coexist (Kavaratzis \& Ashworth, 2008). The first phase concerns place promotion known as "boosterism" (Gold \& Ward, 1994). The second relates to place marketing as a planning tool. While the third phase is place branding as a particular focus of place marketing, and stemming from the merger of interests of marketing development and planning. According to Anholt (2005), the time has come to think of place branding in light of the great changes taking place in the social and political fabric of modern society of the 21st century which force a public-oriented branding approach.

\section{Place Branding Definitions}

"Unfortunately, there is no single accepted definition” (Kavaratzis \& Ashworth, 2005, p. 508) and this is due to the interdisciplinary nature of place branding which has enabled several research areas to participate in the creation of this literature. Indeed, it was built with the contribution from various disciplines including marketing (Kavaratzis, 2005), urban management (R. Petrea, D. Petrea, Olau, \& Filimon, 2013), public relations (Szondi, 2010), international relations (van Ham, 2001), public diplomacy (Gilboa, 2008), geography (Boisen, Terlouw, \& van Gorp, 2011), tourism (Pike, 2007), and more recently branding (Dinnie, 2008). Consequently, many definitions of the concept appeared, differing depending on the angle of approach, generating little agreement on the meaning of place branding and confusion among researchers and practitioners. Indeed, authors such as Kavaratzis and Ashworth (2005), Gertner (2011), Warnaby and Medway (2013), and Boisen, Terlouw, Groote, and Couwenberg (2018) noted the lack of shared definitions about the concept.

In Table 1, we will review some definitions identified during our review of the literature: 
Table 1

Definitions Identified During Our Review of the Literature

\begin{tabular}{|c|c|c|}
\hline Year & Author(s) & Definitions \\
\hline \multirow{2}{*}{2002} & Hall & It is the re-imaging of the national identity. \\
\hline & van Gelder & An attempt to provide relevant meaning and experience to people across multiple societies. \\
\hline \multirow[b]{2}{*}{2004} & Anholt & $\begin{array}{l}\text { The practice of applying brand strategy and other marketing techniques and disciplines to the } \\
\text { economic, social, political, and cultural development of cities, regions, and countries. }\end{array}$ \\
\hline & Gertner and Kotler & $\begin{array}{l}\text { It refers to the strategic image management, which is an ongoing process of researching the place } \\
\text { image, segmenting and targeting specific audiences, positioning to support the desired image, } \\
\text { communicating the attractions to the target groups. }\end{array}$ \\
\hline 2005 & Anholt & $\begin{array}{l}\text { An attempt to manage "the reputation assets" of the place such that reputation results in a "fair, } \\
\text { balanced and useful reflection of its real assets, competencies, offering", thus avoiding biased } \\
\text { cliché determined by history or ignorance. }\end{array}$ \\
\hline 2007 & Pryor and Grossbart & $\begin{array}{l}\text { It is a special case of branding that may differ from other areas of application (e.g., products and } \\
\text { corporations), requiring additional theoretical development. }\end{array}$ \\
\hline \multirow[b]{2}{*}{2009} & Ashworth & $\begin{array}{l}\text { The idea of discovering or creating some uniqueness, which differentiates one place from others in } \\
\text { order to gain a competitive brand value. }\end{array}$ \\
\hline & Govers and Go & $\begin{array}{l}\text { It refers to building brand equity in relation to national, regional and/or local identity: Brand } \\
\text { equity is built through brand loyalty, name awareness, perceived quality. } \\
\text { The creation of a strategic brand identity based on a place's main active value (identity) with the } \\
\text { aim of subsequently placing it on the market by optimising the main passive value (image). The } \\
\text { practice of place branding should be based on three fundamental instances: place identity, place } \\
\text { image, and the consumer experience in the place. }\end{array}$ \\
\hline \multirow{5}{*}{2010} & Anholt & $\begin{array}{l}\text { It is not giving a name or a symbol to a place (places already have names and symbols), but it is } \\
\text { about doing something to enhance the brand image of the place, that is a way to make places } \\
\text { famous. }\end{array}$ \\
\hline & Zenker and Braun & $\begin{array}{l}\text { The process employed by public administrations to intend to create place brands, networks of } \\
\text { associations in the target groups' minds “based on the visual, verbal, and behavioral expression of } \\
\text { a place, which is embodied through the aims, communication, values, and the general culture of } \\
\text { the place's stakeholders and the overall place design. }\end{array}$ \\
\hline & $\begin{array}{l}\text { Ashworth and } \\
\text { Kavaratzis }\end{array}$ & $\begin{array}{l}\text { An attempt to transfer selected meanings (assumed to add value to the place) to the operational } \\
\text { environment of place management. }\end{array}$ \\
\hline & $\begin{array}{l}\text { Kavaratzis and } \\
\text { Ashworth }\end{array}$ & $\begin{array}{l}\text { The means both for achieving competitive advantage in order to increase inward investment and } \\
\text { tourism, but also the means for achieving community development, reinforcing local identity and } \\
\text { identification of the citizens with their city and activating all social forces to avoid social } \\
\text { exclusion and unrest. } \\
\text { The conscious attempt of governments to shape a specifically designed place identity and promote } \\
\text { it to identified markets, whether external or internal. }\end{array}$ \\
\hline & van Ham & $\begin{array}{l}\text { An effort to manage, if not necessarily wield, the social power of a geographical location by using } \\
\text { strategies developed in the commercial sector. }\end{array}$ \\
\hline 2012 & Eshuis and Klijn & $\begin{array}{l}\text { The development of brands for geographical locations, such as regions, cities, or communities, } \\
\text { usually with the aim of triggering positive associations and distinguishing the place from others. }\end{array}$ \\
\hline 2013 & Chan and Marafa & $\begin{array}{l}\text { A process that enhances place image through the experience of an authentic place identity and the } \\
\text { change of mindsets of place consumers. }\end{array}$ \\
\hline 2014 & $\begin{array}{l}\text { Braun, Eshuis, and } \\
\text { Klijn }\end{array}$ & Governance strategy for projecting images and managing perceptions about places. \\
\hline 2016 & Oliveira & $\begin{array}{l}\text { Place branding is not about "propaganda" or communicating to the world the judgment that a } \\
\text { certain place is good, but more about planning for a better place and letting the world know that } \\
\text { authorities and organizations are trying to improve it structurally and strategically. }\end{array}$ \\
\hline
\end{tabular}

Table 1 reveals that place branding does not require a single definition but can accept a variety of definitions justifying then the absence of agreement on its meaning, so it is a polysemic concept. These definitions are not exhaustive because each brings a different but essential aspect to understanding the concept. Definitions have for instance stressed the importance and the objectives of this practice and others on how to apply it and what it 
consists of. However, with the purpose and the "hope" to arrive at the design of a complete definition, it is wise to build it on all the aspects provided by the definitions as well as the results of academic research in the field. Therefore, place branding is a process which:

- determines the place identity, defines its positioning, and strengthens its image to increase its brand equity;

- creates and assigns meaning to places by generating associations in the minds of target customers;

- builds a fair and solid reputation built around the places' strengths and assets;

- differentiates the place from others;

- achieves the place socio-politico-economic objectives and contributes to its overall development.

It is obvious that there is no single and recognized definition of place branding. In the marketing literature, there is a consensus that the brand is more than a name given to a product, nor is it synonymous with a catchy slogan. Places do not suddenly acquire an identity and do not reflect an image with a slogan or logo. However, they can be practical and useful instruments in a place branding strategy, but may, in no case, be the strategy itself. Until today, place branding focused on the visual elements of the brand as the creation of a new logo, a new slogan and at best, developing advertising campaigns to promote these elements. But as the above definitions demonstrate, branding encompasses other areas of activities and interventions that influence and form the place brand. Therefore, branding does not mean promotion and cannot be limited to simple promotional activities. Indeed, place branding should be thought of as a complete and continuous process, interconnected with all marketing efforts (Kavaratzis, 2009). Several authors (Ashworth \& Voogd, 1990; Kotler, Asplund, Rein, \& Haider, 1999) support this idea by admitting that place branding should be considered as a strategic process and not just a promotional activity.

\section{Place Branding Objectives}

Place branding aims to increase the desirability of a place (Arabzadeh \& Aghaeian, 2015). It is focused on creating a favorable image or changing a negative or indifferent place image (Ashworth \& Kavaratzis, 2010). Its main objective is to distinguish the place in a complex and changing market, position it strongly by communicating and valuing its unique advantages and making it an attractive place for investors, tourists, or talents (Cleave, 2014).

According to Hankinson (2015), the goal of place branding is "to maximise economic value and social welfare on behalf of local residents and other stakeholders" (p. 25). In fact, place branding serves various economic, social, and even political objectives because it is an integral part of policies intended to foster the economic restructuring and growth, the increase in the number of foreign investors and tourists, the social development, the social inclusion and cohesion, the community development and involvement, the strengthening of local identity, the place identification and sense of belonging, the general well-being of citizens, the political participation and commitment, besides, to support strategic change within places, and improve their reputation and image externally and internally, among others (Ashworth, 2011; Kavaratzis, 2004; Oliveira, 2016).

Furthermore, many authors stress the role of place branding in the economic development of places. It is considered as a marketing strategy for the economic development (Greenberg, 2008), an important tool for the pursuit of economic development and the maintenance of existing relations with investors and businesses (Papadopoulos, 2004), a tool of a broader economic development strategy that includes the development of public and private infrastructure, the quality of built environment, service design, and planning and public policy, among others (Allen, 2007), and finally, a way to stimulate growth and development of places by attracting 
various resources (Kapferer, 2007), such as economic and financial resources (domestic and foreign companies and investors, tourists and new visitors, etc.), human resources (talents, young executives, new residents, etc.), cultural resources (arts, events, etc.), and so on.

\section{The Conceptual Development of Place Branding}

The academic interest around place branding primarily results from urban policy and tourism (Hankinson, 2010; 2015). Both areas have for long worked independently with little reference to the marketing and branding literature. However, after long years of separate development and literary divorce, an interdisciplinary convergence and a common conceptual development begin to emerge.

Hankinson (2015) traced in Figure 1 the chronological development of place branding:

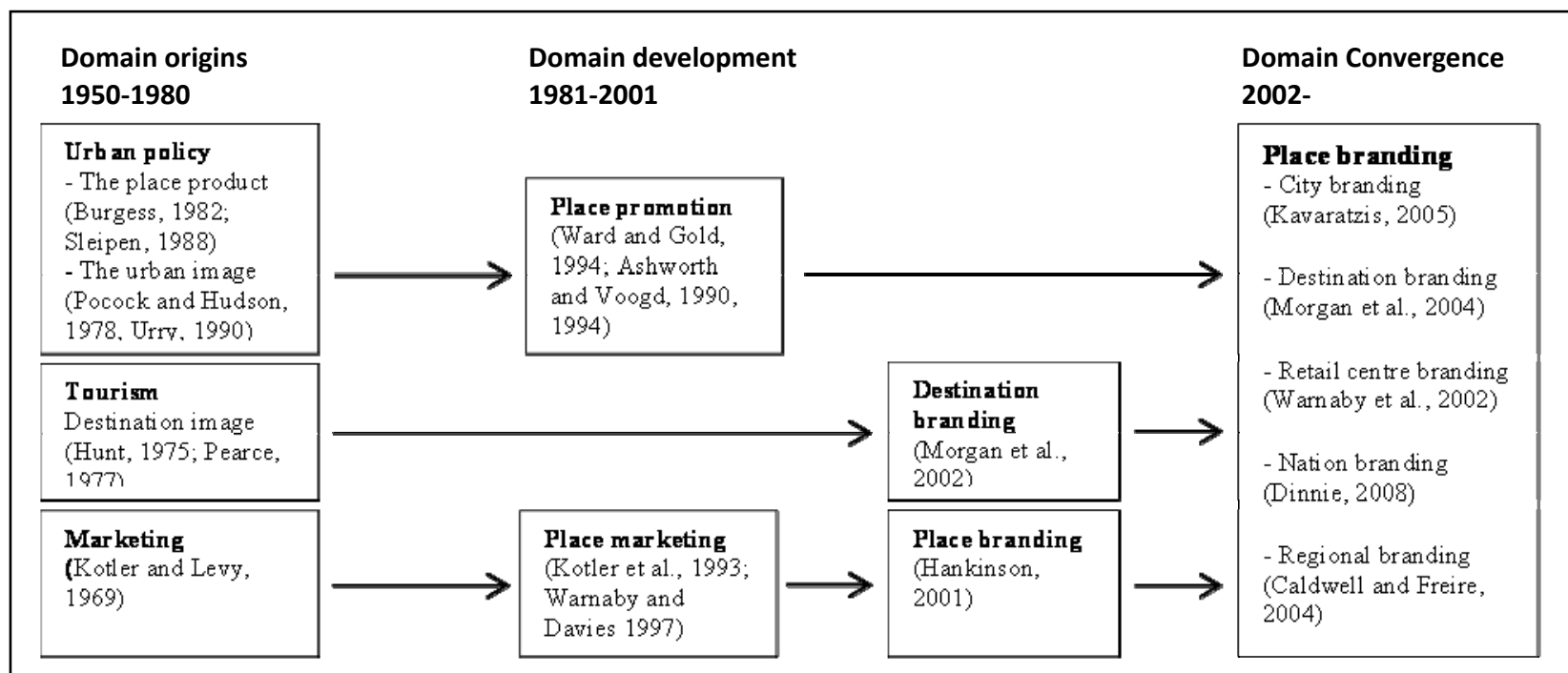

Figure 1. The development of place branding-A timeline. Source: Hankinson (2015).

The development of "place promotion" and "destination branding" has contributed to the formation of place branding, which also benefited from the emergence and development of place marketing. Place branding also has its origins in the development of literature on branding products that highlights two key concepts that are brand image (Gardner \& Levy, 1955; Boulding, 1956) and positioning (Ries \& Trout, 1972). The gradual recognition of the brand as a considerable asset to integrate in the long-term strategies of companies (Tilley, 1999; Urde, 1999) put the focus on other important concepts, such as brand endorsement (Aaker \& Keller, 1990), brand extensions (Park, Milberg, \& Lawson, 1991), brand equity (Keller, 1993), brand architecture (Aaker \& Joachimstaler, 2000), and brand identity (Kapferer, 1997).

Place branding was later tied to the extension of the branding practice that was limited early on to consumer goods only. Indeed, the realization that brands are important assets and that they must reflect and resend to the organization much more than product led to the development of corporate branding (Ind, 1997). Thereby, academic researchers likened places to organizations to the extent that those with strong brands sell their products and services easily, attract people and investors. Several authors (Rainisto, 2003; Kavaratzis, 2004; Trueman, Klemm, \& Giroud, 2004; Kavaratzis \& Ashworth, 2005; Hankinson, 2007) admit that the development of corporate branding has contributed effectively to the formation of place branding, hence the possibility to adopt specificities and approaches of corporate branding and adapt them to the place. 
The adoption of branding by service businesses gave birth to services branding (de Chernatony \& Siegel-horn, 2001). The interest of the researchers toward this type of branding is due to the fact that a place is considered as a grouping of services of different natures because of the presence of tourist resorts, shopping centers, financial places, industrial areas, and cultural and leisure centers. Places provide thus a multitude of services to their different targets. Van den Berg el al. (1990) adopted then the service marketing mix for the branding of cities while Warnaby and Davies (1997) adapted the servuction model to places.

Moreover, the branding of non-profit organizations or non-profit branding solicited the interest of practitioners and academic researchers (Napoli, 2006; Hankinson, 2010) insofar as it shares similar characteristics to place branding. Indeed, place is such a non-profit organization because local officials must cooperate and work with multiple stakeholders who can be either private donors or governmental public organizations. This rapprochement between non-profit branding and place branding was encouraged by the work of Ashworth and Voogd (1990) who assumed that the marketing of non-profit organizations contributed to the development of the theory and practice of place marketing.

Finally, internal branding (Ind, 2001) has emerged following the strategic development of branding activities. It influences largely the success of brands because it is the employees and all the organization staff who are responsible for representing the brand, soaking up and conveying its vision, values, goals, etc. Any brand must be oriented to organizational culture which consists of values, beliefs, attitudes, and employee standards (de Chernatony \& Segal-Horn, 2001; Hatch \& Schulz, 2003; Hankinson, 2009) to ensure the success of the branding strategy. Therefore, internal branding was also solicited to form place branding because in each place there are residents who share beliefs, value systems, traditions, behaviors, attitudes, lifestyles, etc. which form the place's cultural identity. Residents are then the best ambassadors of place brand because they are in daily contact with the other place targets.

\section{Conclusion and Future Research Tracks}

Throughout these last years, place branding sparked worldwide interest focusing the attention of academic researchers, local professionals, and officials. This has spawned the production of a large academic literature on the subject, the creation of specialized blogs, the holding of international conferences, and the development of good and bad practices guides to local stakeholders. Place branding has now become one of the "hot topics" in the world. This worldwide infatuation is explained by fierce competition between places that are looking for ways to differentiate themselves and create competitive advantage. The planning of a place branding strategy proves to be the solution to achieve the development and attractiveness goals of places.

The literature review was conducted following the analysis of articles published in journals of various kinds (political, management, tourism, marketing, site branding, planning, etc.), which makes place branding an interdisciplinary field gathering different concepts and covers countless topics. The review of articles helped to highlight some findings. First, the literature has not resulted in the construction of a solid theory about place because "it is difficult to see how a field of study or practice can mature unless some kind of consensus is reached on the definition of the field" (Anholt, 2010, p. 1). In addition, most of the articles are qualitative, based on personal opinions or case studies. Articles are then factual and descriptive. Almost none of the articles analyzed are quantitative or provide models and testable hypotheses. Therefore, it is now time to develop frameworks and theoretical models where relationships between variables can be tested empirically. 
The lack of a conceptual framework has prompted researchers to develop a theory and build a place branding process as they support that the creation of a place brand can positively change perceptions associated with a place. This concept is recent but draws its basis from the practice of "place promotion" and "place selling". The evolution of marketing and its branding strategy, and their adaptation to different fields apart from consumer products, motivated different authors and academic researchers in marketing to give special importance to this new concept given the many research opportunities associated. Then, they assimilated places to organizations by developing corporate branding, services branding, non-profit branding, and internal branding. Although these four branding strategies were the subject of a separate literature, it remains insufficient particularly in relation to place branding, hence the need to develop these strategies further. Other concepts related to the brand were identified (brand image, brand identity, positioning, brand equity, brand architecture, and brand extensions) but require deepening and extensive research to transfer them to place branding and adapt them to places. Indeed, research and articles on the application of concepts in branding and their degree of adaptability to places are nevertheless limited although place branding professionals widely acknowledge the contribution of these strategies for the promotion of places. So, there is a need for more specification of the key concepts involved in the formation of place branding as well as a better understanding of these concepts to allow empirical research move forward. Future empirical research will need to assess especially the relevance and the potential of transferability of concepts in order to clearly specify their role in the formation of place brands. Otherwise, it should also be noted that special attention was paid to brand image through research, while articles dealing with and deepening other concepts are fewer.

A key point to discuss and develop in future research relates to the complex nature of place. Indeed, we cannot consider places as mere consumption products or organizations and systematically implement branding strategies and various marketing tools and techniques without taking into account their characteristics and specificities. This is a simplistic approach to the concept of place, which can influence the success of place branding strategy.

Since place branding aims to develop and promote the various aspects of the place (socio-economic, tourist, cultural, etc.) and it has a multitude of stakeholders and various targets, can we then consider a place brand as an umbrella brand? Can a brand cover and contain all the dimensions of a place and reflect it as a single place? If the answer is no, do we have to create a brand for each target? Would it still be place branding? Research should be developed in this direction in order to provide answers.

On the other hand, the importance and the role of residents in the place branding process have not been the subject of extensive research. In general, articles are focused on the two main targets of places namely visitors and investors, and have neglected residents who are both targets of the place branding process and major players in the latter. They are also the first and the best ambassadors of the place brand. In future research, special focus should be directed to the different roles of residents in the process to find out how they can contribute to the creation and success of the place brand.

Furthermore, place brands differ from commercial brands as they do not belong to a single organization, but they are developed and supported by a broad network of public and private actors. Stakeholder management is a relevant research area because the quality of relations between brand managers and all stakeholders is crucial to the success of a place brand. Future research should focus on how to maintain good relations with stakeholders and ensure their long-term commitment, and the role of everyone in the brand's creation and delivery. Brand financing also represents a future research track especially as public funding is still insufficient and requires the 
mobilization of private actors. Research is needed to find long-term financing solutions and alternatives to those provided by public and private sector actors in order to ensure good financial health of the brand.

Finally, the measure of a place brand performance is essential to assess the success, effectiveness, value created, and the changes caused by the branding strategy on places and thus turns out to be a complex issue that requires further research.

After long years of research and contributions to the place branding field, it may seem that this discipline has reached a sufficient degree of literary maturity but it is clear that there is still a huge job to do in order to generate a comprehensive understanding and get to apply branding to places. This is mainly due to the interdisciplinary nature of this field of research. Nevertheless, a significant part of the work has already been done, and problems of this area of research continue to grow.

\section{References}

Aaker, D., \& Joachimstaler, E. (2000). Brand leadership. New York: The Free Press.

Aaker, D., \& Keller, K. L. (1990). Consumer evaluations of brand extensions. Journal of Marketing, 54(1), 27-41.

Allen, G. (2007). Place branding: New tools for economic development. Design Management Review, 18(4), 60-69.

Anholt, S. (1998). Nation brands of the twenty-first century. Journal of Brand Management, 5(6), 395-406.

Anholt, S. (2004). Foreword to the first issue. Place Branding and Public Diplomacy, 1(1), 4-11.

Anholt, S. (2005). Some important distinctions in place branding. Place Branding and Public Diplomacy, 1(2), 116-121.

Anholt, S. (2008). Editorial. Place Branding and Public Diplomacy, 4(2), 97-101.

Anholt, S. (2010). Definitions of place branding-Working towards a resolution. Place Branding and Public Diplomacy, 6(1), $1-10$.

Arabzadeh, E., \& Aghaeian, S. (2015). Malaysia’s place branding in today competitive globalized market. International Journal of Advanced Research in Management and Social Sciences, 4(8), 128-139.

Ashworth, G. J. (2009). The instruments of place branding: How is it done? European Spatial Research and Policy, 16(1), 9-22.

Ashworth, G. J. (2011). Should we brand places? Journal of Town and City Management, 1(3), 248-252.

Ashworth, G. J., \& Kavaratzis, M. (2010). Towards effective place brand management: Branding European cities and regions. Cheltenham: Elgar.

Ashworth, G. J., \& Voogd, H. (1990). Selling the city: Marketing approaches in public sector urban planning. London: Belhaven Press.

Balmer, J. M. T., \& Greyser, S. A. (2003). Revealing the corporation: Perspectives on identity, image, reputation, corporate branding and corporate-level marketing. London: Routledge.

Bartels, C. P. A., \& Timmer, M. (1987). City marketing: Instruments and effects. Proceedings of the 27th European Congress of Regional Science Association Conference, August 25-28, Athens, Greece.

Boisen, M., Terlouw, K., \& van Gorp, B. (2011). The selective nature of place branding and the layering of spatial identities. Journal of Place Management and Development, 4(2), 135-147.

Boisen, M., Terlouw, K., Groote, P., \& Couwenberg, O. (2018). Reframing place promotion, place marketing, and place branding-moving beyond conceptual confusion. Cities, 80, 4-11.

Boulding, K. (1956). The image. Ann Arbor, MI: University of Michigan Press.

Braun, E., Eshuis, J., \& Klijn, E. H. (2014). The effectiveness of place brand communication. Cities, 41, 64-70.

Chan, C. S., \& Marafa, L. M. (2013). A review of place branding methodologies in the new millennium. Place Branding and Public Diplomacy, 9(4), 236-253.

Cleave, E. P. (2014). Economic development in the contemporary global environment: The role of place branding as a tool of local economic development in Ontario, Canada (Doctoral thesis, University of Western Ontario, Canada).

De Chernatony, L., \& Segal-Horn, S. (2001). Building on services' characteristics to develop successful services brands. Journal of Marketing Management, 17(7-8), 645-670.

Dinnie, K. (2008). Nation branding: Concepts, issues, practice. Oxford: Butterworth Heinemann.

Eshuis, J., \& Klijn, E. H. (2012). Branding in governance and public management. London: Routledge.

Gardner, B., \& Levy, S. (1955). The product and the brand. Harvard Business Review, March-April, 33-39. 
Gertner D. (2011). A (tentative) meta-analysis of the "place marketing” and "place branding” literature. Journal of Brand Management, 19(2), 112-131.

Gertner, D., \& Kotler, P. (2004). How can a place correct a negative image? Place Branding, 1(1), 50-57.

Gilboa, E. (2008). Searching for a theory of public diplomacy. The ANNALS of the American Academy of Political and Social Science, 616(1), 55-77.

Gold, J., \& Ward, S. (Eds.) (1994). Place promotion: The use of publicity and marketing to sell places. Chichester, UK: John Wiley and Sons.

Govers, R., \& Go, F. M. (2009). Place branding: Global, virtual and physical, identities constructed, imagined and experienced. Basingstoke, Hampshire, UK: Palgrave Macmillan.

Greenberg, M. (2008). Branding New York: How a city in crisis was sold to the world? London: Routledge.

Hall, D. (2002). Brand development, tourism and national identity: The re-imaging of former Yugoslavia. Journal of Brand Management, 9(4-5), 323-334.

Hankinson, G. (2001). Location branding: A study of the branding practices of 12 English cities. Journal of Brand Management, $9(2), 127-142$.

Hankinson, G. (2007). The management of destination brands: Five guiding principles based on recent developments in corporate branding. Journal of Brand Management, 14(3), 240-254.

Hankinson, G. (2009). Managing destination brands: Establishing a theoretical foundation. Journal of Marketing Management, 25(1-2), 97-115.

Hankinson, G. (2010). Place branding research: A cross disciplinary agenda and the views of practitioners. Place Branding and Public Diplomacy, 6(4), 300-315.

Hankinson, G. (2015). Rethinking the place branding construct. In M. Kavaratzis, G. Warnaby, and G. Ashworth (Eds.), Rethinking place branding (pp. 13-31). Switzerland: Springer International Publishing.

Hatch, M. J., \& Schulz, M. (2003). Bringing the corporation into corporate branding. European Journal of Marketing, 37(7-8), 1041-1064.

Ind, N. (1997). The corporate brand. London: MacMillan.

Ind, N. (2001). Living the brand. London: Kogan Page.

Kapferer, J. (1997). Strategic brand management. London: Kogan Page.

Kapferer, J. N. (2007). Les marques capital de l'entreprise, créer et développer des marques fortes. Paris: Editions d'Organisation.

Kavaratzis, M. (2004). From city marketing to city branding: Towards a theoretical framework for developing city brands. Journal of Place Branding, 1(1), 58-73.

Kavaratzis, M. (2005). Place branding: A review of trends and conceptual models. The Marketing Review, 5(4), 329-342.

Kavaratzis, M. (2009). Cities and their brands: Lessons from corporate branding. Place Branding and Public Diplomacy, 5(1), 26-37.

Kavaratzis, M., \& Ashworth, G. J. (2005). City branding: An effective assertion of identity or a transitory marketing trick? Tijdschrift voor Economische en Sociale Geografie, 96(5), 506-514.

Kavaratzis, M., \& Ashworth, G. J. (2008). Place marketing: How did we get here and where are we going? Journal of Place Management and Development, 1(2), 150-165.

Kavaratzis, M., \& Ashworth, G. J. (2010). Place branding: Where do we stand? In G. J. Ashworth and M. Kavaratzis (Eds.), Towards effective place brand management: Branding European cities and regions (pp. 1-15). Cheltenham: Edward Elgar.

Kearns, G., \& Philo, C. (Eds.). (1993). Selling places: The city as cultural capital, past and present. Oxford, UK: Pergamon.

Keller, K. L. (1993). Conceptualising, measuring and managing customer-based brand equity. Journal of Marketing, 57(1), 1-22.

Kotler, P., Asplund, C., Rein, I., \& Haider, D. (1999). Marketing places Europe: How to attract investments, industries, residents and visitors to cities, communities, regions and nations in Europe. London: Pearson Education Limited.

Kotler, P., Haider, D. H., \& Rein, I. (1993). Marketing places: Attracting investment, industry and tourism to cities, states and nations. New York: The Free Press.

Napoli, J. (2006). The impact of non-profit brand orientation on organisational performance. Journal of Marketing Management, 22(7), 673-694.

Oliveira, E. (2016). Place branding in strategic spatial planning-An analysis at the regional scale with special reference to Northern Portugal (Doctoral thesis, University of Groningen, Netherlands).

Papadopoulos, N. (2004). Place branding: Evolution, meaning and implications. Place Branding, 1(1), 36-49. 
Park, C. W., Milberg, S., \& Lawson, R. (1991). Evaluation of brand extensions: The role of product feature similarity and brand concept consistency. Journal of Consumer Research, 18, 185-193.

Pasquinelli, C. (2012). Competition, cooperation, co-opetition: Widening the perspective on place branding. Retrieved December 15, 2015, from http://www.phdmanagement.sssup.it/documenti/awarded/pasquinelli_thesis.pdf

Petrea, R., Petrea, D., Olau, P. E., \& Filimon, L. (2013). Place branding as efficient management tool for local government. Transylvanian Review of Administrative Sciences, 9(SI), 124-140.

Pike, S. (2007). Consumer-based brand equity for destinations: Practical DMO performance measures. Journal of Travel \& Tourism Marketing, 22(1), 51-61.

Pryor, S., \& Grossbart, S. (2007). Creating meaning on main street: Towards a model of place branding. Place Branding and Public Diplomacy, 3, 291-304.

Rainisto, S. K. (2003). Success factors of place marketing: A study of place marketing practices in Northern Europe and the United States (Ph.D. thesis, Helsinki University of Technology, Institute of Strategy and International Business).

Ries, A., \& Trout, J. (1972). The positioning era cometh. Advertising Age, 24, 35-38.

San Eugenio Vela, J. (2013). Place branding: A conceptual and theoretical framework. Boletin de la Asociacion de Geografos Espanoles, (62), 467-471.

Szondi, G. (2010). From image management to relationship building: A public relations approach to nation branding. Place Branding and Public Diplomacy, 6(4), 333-343.

Tilley, C. (1999). Built-in branding: How to engineer a leadership brand. Journal of Marketing Management, 15(1-3), $181-191$.

Trueman, M., Klemm, M., \& Giroud, A. (2004). Can a city communicate? Bradford as a corporate brand. Corporate Communications: An International Journal, 9(4), 317-330.

Urde, M. (1999). Brand orientation: A mindset for building brands into strategic resources. Journal of Marketing Management, 15(1-3), 117-133.

Van den Berg, L., Klaasen, L., \& van der Meer, J. (1990). Marketing metropolitan regions. Rotterdam, the Netherlands: European Institute of Comparative Urban Research.

Van Gelder, S. (2002). General strategies for global brands. Brand Meta. Retrieved from http://www.brand-meta.com

Van Ham, P. (2001). The rise of the brand state. Foreign Affairs, 80(5), 2-8.

Van Ham, P. (2010). Social power in international politics. Abingdon: Routledge.

Ward, S. (1998). Selling places: The marketing of towns and cities, 1850-2000. London: Routledge.

Warnaby, G., \& Davies, B. (1997). Commentary: Cities as service factories? Using the servuction system for marketing cities as shopping destinations. International Journal of Retail \& Distribution Management, 25(6), 204-210.

Warnaby, G., \& Medway, D. (2013). What about the “place” in place marketing? Journal of Marketing Theory, 13(3), 345-363.

Zenker, S., \& Braun, E. (2010). Branding a city—A conceptual approach for place branding and place brand management. Paper presented at the 39th European Marketing Academy Conference, June 1-4, Copenhagen, Denmark. 